\title{
Tinjauan Tingkat Kondisi Fisik Pemain Bolavoli Putra Sma 2 Pariaman
}

\author{
Nanda Saputra ${ }^{1}$, Ishak Aziz ${ }^{2}$ \\ ${ }^{1,2}$ Fakultas Ilmu Keolahragaan,Universitas Negeri Padang, Indonesia. \\ E-mail: saputrananda469@gmail.com ${ }^{1}$, ishakaziz@fik.unp.ac.id ${ }^{2}$
}

Informasi Artikel

Diterima

Direvisi

Dipublikasikan 10-06-2020

\section{Keyword:}

Leg Muscle Explosive Power Arm Muscle Explosive Power Endurance Volleyball

\begin{abstract}
The problem in this study is the low achievement achieved by male volleyball players in Pariaman 2 High School. This type of research is descriptive which aims to reveal a description of the physical conditions possessed. The population in this study were all male volleyball players in Pariaman 2 Senior High School, totaling 14 people registered in extracurricular activities at school. Sample technique at the total sample is 14 people. The instrument used to measure leg muscle explosive power with a vertical jump test, arm muscle explosive power with a one hand medicine ball putt, and endurance used with $\mathrm{VO}_{2}$ max was a bleep test. Data were analyzed using the formula of frequency distribution in the form of a percentage $P=F / N$ $X 100 \%$. Based on data analysis, the results of the study are as follows (1) leg muscle explosive power obtained an average value of $91.40 \mathrm{k4}$ $\mathrm{m} / \mathrm{sec}$ meter is considered sufficient; (2) arm muscle explosive power obtained an average value of 8.68 meters is considered sufficient; (3) endurance obtained an average value of 40.26 with enough categories.
\end{abstract}

(c) 2020 The Authors. Published by Universitas Negeri Padang. This is an open access article under the CC BY-NC-SA license (https://creativecommons.org/licenses/by-nc-sa/4.0

\section{Penulis Korespondensi:}

Nanda Saputra

Universitas Negeri Padang

Email: saputrananda469@gmail.com

\section{PENDAHULUAN}

Olahraga merupakan kegiatan yang dibutuhkan oleh setiap orang, dengan berolahraga yang teratur seseorang akan mendapatkan kesegaran jasmani, kesegaran pemikiranya sehingga dapat meningkatkan produktifitas kerja. Olahraga mempunyai yang mana tidak saja hanya untuk kesehatan, prestasi, pendidikan tetapi olahraga juga sebagai sarana untuk membina dan mempererat persatuan dan kesatuan bangsa yang nantinya berpengaruh terhadap pembangunan nasional.

Dalam Undang-Undang Republik Indonesia No. 3 Tahun 2005 tentang Sistem Keolahragaan Nasional pasal 4 berbunyi "Keolahragaan nasional bertujuan untuk memilihara dan meningkatkan kesehatan dan kebugaran prestasi, kualitas manusia, menanamkan nilai moral dan akhlak yang mulia, sportifitas dan disiplin, mempererat dan membina persatuan dan kesatuan bangsa, memperkukuh ketahanan nasional, serta mengangkat harkat, martabat, dan kehormatan bangsa".

Berdasarkan kutipan di atas jelas bahwa olahraga termasuk salah satu tujuan yang akan dicapai dalam usaha pembinaan dan pengembangan olahraga yang merupakan upaya meningkatkan kualitas bangsa Indonesia. Melalui kegiatan olaharaga kita harapkan dapat 
menciptakan suatu penampilan sikap baru dari seluruh bangsa Indonesia dalam mengisi pembangunan.

Berbicara tentang prestasi olahraga merupakan suatu hal yang tidak mudah, prestasi olahraga akan terwujud bila adanya kerjasama yang baik antara pemerintah, masyarakat dan insan olahraga. Banyak sekali cabang olahraga yang digemari masyarakat dan salah satu yang populer di seluruh kalangan masyarakat di dunia adalah bolavoli, karena olahraga ini tidak sulit dipelajari dan tidak membutuhkan dan biaya yang mahal. Sampai saat ini bolavoli masih dianggap sebagai olahraga yang cukup populer di dunia, ini terbukti dengan banyaknya kejuaraan-kejuaraan yang di gelar di berbagai daerah baik kejuaraan tingkat daerah, nasional maupun internasional. Untuk membina dan mengembangkan olahraga bolavoli menuju prestasi yang maksimal dan tidak terlepas dari unsur-unsur yang akan mendukung tercapainya prestasi tersebut.

Tingkat kondisi fisik pemain bolavoli putra SMA 2 Pariaman perlu di ketahui melalui suatu penelitian. Komponen-komponen kondisi fisik tersebut, mempunyai karakter umum dan khusus untuk bisa memperoleh prestasi puncak dalam permainan bolavoli. Maka setiap pemain harus memulai latihan kondisi fisik umum terlebih dahulu, di samping itu kondisi fisik khusus merupakan hal yang sangat penting karena kondisi fisik khusus merupakan hal yang sangat penting karena kondisi fisik khusus bertujuan antara lain dalam membangun kekuatan lompatan, kekuatan pukulan dan dayatahan.

Kompetensi pelatih dapat mempengaruhi prestasi, Pelatih adalah seorang profesional yang tugasnya membantu tim dalam memperbaiki penampilan tim. Dalam pencapaian prestasi yang setinggi-tingginya, pelatih adalah aktor penting. Tingkat keberhasilan dari pelatih adalah jika mampu menghantarkan timnya meningkatkan kemampuan dan prestasi setinggi-tingginya.

Penguasaan teknik dan pemahaman taktik dapat mempengaruhi prestasi pemain. Teknik dasar merupakan suatu keterampilan penting yang harus di miliki seorang atlet sebelum menuju kemahiran maka dari itu teknik dasar diperlukan oleh atlet untuk meraih prestasi. Taktik adalah suatu siasat atau akal yang dirancang dan akan dilaksanakan dalam permaianan oleh perorangan, kelompok, maupun tim untuk memenangkan suatu pertandingan secara sportif. Pada hakikatnya penggunaan taktik dalam bolavoli adalah suatu usaha mengembangkan kemampuan berfikir, kreativitas, serta improvisasi untuk menetukan cara terbaik memecahkan masalah yang di hadapi dalam suatu pertandingan secara efektif, efesien, dan produktif dalam rangka memperoleh hasil yang maksimal yaitu sebuah kemenangan dalam pertandingan.

Mental juga dapat mempengaruhi prestasi pemain. Untuk dapat meningkatkan prestasi atau peforma olahraganya, pemain perlu memiliki mental yang kuat dan tangguh. Dilihat dari segi lapangan bolavoli putra SMA 2 Pariaman, sarana dan prasarana cukup memadai seperti mempunyai lapangan bolavoli yang bagus dan terawat, memiliki dua buah net yang masih layak di pakai dan mempunyai 8 buah bola yang layak di pakai dan bagus untuk menunjang latihan.

Berdasarkan observasi pada tanggal 25 November 2019 di lapangan, bahwa prestasi tim bolavoli putra SMA 2 Pariaman dapat dikatakan mengalami penurunan prestasi yang cukup signifikan, ini terlihat dari rangkuman sejumlah turnamen yang di ikuti di MAN 1 Kota Padang Panjang oleh SMA 2 Pariaman, Pada tahun 2017 tim bolavoli putra SMA 2 Pariaman mendapatkan peringkat ke 1. Pada turnamen antar sekolah se-Sumatera Barat di MAN 1 Padang Panjang tahun 2018, justru prestasi tim bolavoli putra SMA 2 Pariaman hanya masuk babak 8 besar, selanjutnya prestasi tim bolavoli putra SMA 2 Pariaman pada tahun 2019 yang juga mengikuti turnamen bolavoli se-Sumatera Barat mengalami penurunan prestasi yang sangat mengecewakan karena tim bolavoli putra SMA 2 Pariaman gagal di babak penyelisihan. Hal ini dikarenakan tim bolavoli putra SMA 2 Pariaman tidak mempunyai kekuatan lompatan, kekuatan pukulan,dan mengalami kelelahan yang pada saat bertanding sehingga mempengaruhi teknik, taktik, mental (psikis) pemain bolavoli putra SMA 2 Pariaman. Daya ledak adalah gabungan dari dua kemampuan yaitu kekuatan (strenght) dan kecepatan (speed) untuk melakukan dalam waktu yang sangat cepat. Daya ledak otot tungkai yang guna nya untuk mencapai ketinggian lompatan vertical. Daya ledak otot lengan merupakan salah satu komponen fisik yang harus dimiliki seorang pemain bolavoli, baik itu sewaktu melakukan servis maupun smash.Dayatahan aerobik ( $\mathrm{VO}_{2} \max$ ) yaitu kemampuan paru jantung menyuplai oksigen untuk kerja otot dalam waktu yang lama. Dayatahan aerobik disebut juga dayatahan paru jantung, dayatahan merupakan komponen komponen dari kondisi fisik yang sangat diperlukan dalam permainan bolavoli. 
Jika hal ini di biarkan maka prestasi maksimal yang dihrapkan SMA 2 Pariaman akan sulit untuk diraih, untuk itu peneliti tertarik melakukan penelitian dengan judul "Tinjauan tingkat kondisi fisik pemain bolavoli putra SMA 2 Pariaman". Sehingga dari hasil penelitian ini bisa melahirkan suatu kesimpulan yang dijadikan salah satu solusi dalam menyelesaikan permasalahan yang terjadi, atau dapat juga dijadikan sebagai langkah antisipasi bagi peningkatan persiapan kondisi fisik yang merupakan salah satu faktor pendukung dalam pencapaian prestasi pemain bolavoli putra SMA 2 Pariaman.

Permaianan bolavoli di Indonesia sudah dikenal sejak tahun 1928, di mana negeri ini masih berada dalam belunggu penjajahan. Awalanya yang memperkenalkan permaianan ini adalah guru-guru Belanda yang mengajar disekolah-sekolah lanjutan seperti HBS dan AMS sebagai dari pendidikan jasmani maupun rekreatif. (Erianti, 2014)

Ide dasar permaianan bolavoli itu adalah memasukan bola kedaerah lawan melewati suatu rintangan berupa tali atau net. Kemudian untuk memenangkan permaianan dengan cara mematikan bola di daerah lawan. Permainan bolavoli artinya memantulkan (memainkan) bola di udara sebelum bola jatuh atau bola menyentuh lantai.

Menurut Bacthiar (1999) ide permainan bolavoli adalah: "permainan beregu, setiap regu berada pada petak lapangan permainan masing-masing yang dibatasi oleh net dan bola dimainkan dengan satu atau dua tangan atau bagian tubuh lainnya hilir mudik melalui atas net secara teratur sampai bola menyentuh lantai (mati) di petak lapangan lawan dan mempertahankan agar bola tidak mati di petak sendiri.

Dari pendapat di atas, dapat disimpulkan bahwa pada hakekatnya permainan bolavoli merupakan permainan yang dimainkan oleh regu yang terdiri dari enam orang, dibatasi oleh net dan bola dimainkan satu atau dua tangan atau bagian tubuh lainya sampai bola menyentuh lantai (mati) di petak lawan dan mempertahan kan bola agar tidak mati di petak lapangan sendiri.

Kondisi fisik menurut Jonath Krempel (1981) dalam Irawadi (2018) mengartikan bahwa "kondisi fisik merupakan keadaan yang meliputi faktor kekuatan, kecepatan, dayatahan, kelentukan/kelenturan dan koordinasi".

Menurut Hendri Irawadi (2010) dalam Saputra dkk,"keberhasilan atau prestasi seseorang dalam berolahraga sangattergantung pada kualitas kemampuan fisik (kondisi fisik) yang dimilikinya". Semakinbaik kondisi atau kemampuan fisik seseorang, maka semakin besar peluangnya untuk berprestasi. Begitu juga sebaliknya, semakin rendah tingkat kondisi fisiknya maka semakin sulit ia untuk meraih prestasi.

Dalam memainkan bolavoli pemain membutuhkan kondisi fisik yang baik, karena kondisi fisik yang baik akan membantu pemain dalam melakukan gerakan-gerakan dalam permainan bolavoli. Dalam olahraga bolavoli untuk menghadapi suatu pertandingan harus siap dengan kondisi fisik yang prima. Apa bila kondisi fisiknya tidak prima maka akan mempengaruhi teknik bolavoli dan lemah dalam melakukan serangan ke daerah pertahanan lawan, seperti melakukan smash ataupun kecepatan mengantisipasi bola smash tipuan lawan dalam permainan bolavoli.

Tujuan latihan kondisi fisik adalah untuk meningkatkan kualitas fungsional organ tubuh sesuai dengan kebutuhan dan tuntunan untuk mencapai prestasi yang optimal dalam suatu cabang olahraga tertentu. Persiapan kondisi fisik sangatlah penting untuk meningkatkan dan memantapkan kualitas teknik, tanpa persiapan kondisi fisik yang memadai maka akan sulit untuk mencapai prestasi yang tinggi. Misalnya saja dalam permainan bolavoli, untuk mempelajari teknik smash seorang pemain harus memiliki power kaki, power lengan dan dayatahan yang cukup baik sehingga ia mampu melompat yang tinggi untuk memukul bola di atas net.

Secara umum masing-masing cabang olahraga membutuhkan kondisi fisik yang sama, artinya setiap cabang olahraga membutuhkan kondisi fisik dalam usaha mencapai prestasi yang maksimal begitu pula halnya dengan olahraga bolavoli. Ada 2 macam kondisi fisik, yaitu:

Kondisi fisik umum merupakan program pengembangan yang bersifat menyeluruh. Kondisi fisik umum adalah semua kemampuan jasmani atlet secara umum yang merupakan kondisi awal tubuh sebelum mengikuti latihan secara khusus yang direalisasikan melalui kemampuan pribadi dan diperlukan untuk semua cabang olahraga (Efendy Firdaus, 2017). Secara umum kondisi fisik yang diperlukan dalam masing-masing olahraga adalah sama, artinya setiap cabang olahraga memerlukan kondisi fisik dalam usaha mencapai prestasi yang optimal, begitu halnya dalam olahraga bolavoli. Seseorang dapat dikatakan dalam keadaan kondisi fisik yang baik 
jika ia mampu melakukan pekerjaan yang dibebankan kepadanya atau yang ingin dilakukan tanpa kelelahan yang berlebihan.

Kemampuankondisi fisik khusus menunjukkan ke khususan suatu cabang olahraga karena kebutuhan terhadap kemampuan, ini akan berbeda antara suatu cabang olaraga dengan dengan cabang olahraga lainnya.Menurut Erianti (2004) "tujuan utama dalam pembinaan kondisi fisik khusus adalah untuk memperdalam perkembangan unsur-unsur kondisi fisik yang lebih spesifik sesuai dengan tuntunan olahraga".

Berdasarkan dari kategori olahraga bolavoli yang tergolong dalam olahraga yang membutuhkan kondisi fisik yang prima, maka beberapa unsur-unsur kondisi fisik yang dibutuhkan dalam suatu pertandingan bolavoli diantaranya: daya ledak otot tungkai, daya ledak otot, dayatahan.

\section{METODE}

Jenis penelitian ini adalah penelitian bersifat deskriptif,menurut Arikunto (2010) "penelitian deskriptif adalah penelitian yang dimaksudkan untuk menyelidiki keadaan, kondisi atau hal lainlain yang sudah disebutkan, yang hasilnya dipaparkan dalam bentuk laporan penelitian". Dengan demikian penelitian ini bertujuan untuk mengungkapkan atau menggambarkan tentang tingkat kondisi fisik pemain bolavoli putra SMA 2 Pariaman.Waktu penelitian ini dilaksanakan pada bulan Maret 2020dantempat penelitiandi lapangan SMA 2 Pariaman,populasi dalam penelitian ini adalah seluruh pemain bolavoli putra SMA 2 Pariaman berjumlah 14 orang yang terdaftar pada kegiatan Eksrtrakulikuler di sekolah.Pengambilan sampel dilakukan secara sample jenuh hal yakni teknik penentuan sampel bila semua anggota populasi digunakan sebagai sampel, hal ini sering dilakukan bila jumlah populasi relatif kecil dari 30 orang atau penelitian yang ingin membuat generalisasi dengan kesalahan yang sangat kecil. (Aziz, 2016). Instrumen penelitian adalah Vertical Jump Test, One Hand Medicine Ball Putt Test, Dayatahan Aerobik ( $\mathrm{VO}_{2} \mathrm{max}$ ). Teknik analisis data yang digunakan dalam penelitian ini adalah teknik distribusi frekuensi (statistik deskriptif) dengan perhitungan persentase, seperti dijelaskan Sudidjono dalam Setiawan dkk (2018)“Bila suatu penelitian bertujuan mendapatkan gambaran atau menemukan sesuatu sebagaimana adanya tentang sesuatu objek yang diteliti maka teknik analisis yang dibutuhkan cukup dengan perhitungan persentase". Dengan rumus $P=\frac{F}{N} \mathrm{X} 100 \%$.

\section{HASIL DAN PEMBAHASAN}

\section{Hasil Penelitian}

\section{Daya Ledak Otot Tungkai}

Berdasarkan hasil tes daya ledak otot tungkai pemain bolavoli putra SMA 2 Pariaman, dengan menggunakan Vertical Jump Test di peroleh skor maksimum 135,51 kg m/sec tergolong kategori baik sekali dan skor minimum $58,34 \mathrm{~kg} \mathrm{~m} / \mathrm{sec}$ tergolong kategori kurang. Berdasarkan hasil analisis data daya ledak otot tungkai pemain bolavoli putra SMA 2 Pariaman diperoleh data distribusi frekuensi sebagai berikut rata-rata tingkat daya ledak otot tungkai pemain bolavoli putra SMA 2 Pariaman adalah $91,40 \mathrm{~kg} \mathrm{~m} / \mathrm{sec}$ tergolong kategori cukup. Data penelitian menunjukkan dari 14 orang, 1 orang (7,14\%) memiliki daya ledak otot tungkai $126,31 \mathrm{~kg} \mathrm{~m} / \mathrm{sec}$ tergolong baik sekali, 4 orang $(28,57 \%)$ memilki daya ledak otot tungkai $103.03-126.30 \mathrm{~kg} \mathrm{~m} / \mathrm{sec}$ tergolong kategori baik. 5 orang (35,72\%) memiliki daya ledak otot tungkai $79,77-103,02 \mathrm{~kg}$ $\mathrm{m} / \mathrm{sec}$ kategori cukup. Dan 4 orang (28,57 \%) memiliki daya ledak otot tungkai 56,50 - 79,76 kg $\mathrm{m} / \mathrm{sec}$ dengan kategori kurang. Sedangkan untuk klasifikasi kurang sekali tidak ada (0\%) yang dimiliki oleh pemain bolavoli putra SMA 2 Pariaman.

\section{Daya ledak otot lengan}

Berdasarkan hasil tes daya ledak otot lengan untuk pemain bolavoli putra SMA 2 Pariaman, diperoleh nilai maksimum 10,45 meter tergolong kategori baik dan nilai minimum 5,91 meter tergolong kategori kurang sekali. Berdasarkan hasil analisis data daya ledak otot lengan pemain bolavoli putra SMA 2 Pariaman diperoleh data distribusi frekuensi sebagai berikut rata-rata tingkat daya ledak otot lengan pemain bolavoli putra SMA 2 Pariaman adalah 8,64 meter tergolong kategori cukup. Data penelitian menunjukkan dari 14 orang pemain bolavoli putra SMA 2 
Pariaman, 4 orang (28,56\%) memiliki daya ledak otot lengan 9,31 - 10,56 meter tergolong baik, 6 orang $(42,86 \%)$ memilki daya ledak otot lengan 8.05 - 9.30 meter tergolong kategori cukup, 2 orang $(14,29 \%)$ memiliki daya ledak otot lengan 6,79-8,04 meter tergolong kategori kurang, dan 2 orang $(14,29 \%)$ memiliki daya ledak otot lengan $<6,79$ meter tergolong kategori kurang sekali. Inilah hasil daya ledak otot lengan yang dimiliki oleh pemain bolavoli putra SMA 2 Pariaman.

\section{Dayatahan}

Berdasarkan hasil tes $\mathrm{VO}_{2} \max$ pemain bolavoli putra SMA 2 Pariaman. diperoleh nilai maksimum 44,5 tergolong kategori baik sekali dan skor minimum 36 tergolong kategori kurang.

Berdasarkan hasil analisis data dayatahan pemain bolavoli putra SMA 2 Pariaman diperoleh data distribusi frekuensi sebagai berikut, rata-rata dayatahan pemain bolavoli putra SMA 2 Pariaman adalah 40,26 yang tergolong kategori cukup. Data penelitian menunjukkan dari 14 orangpemain bolavoli putra SMA 2 Pariaman, 5 orang (35,71\%) memiliki dayatahan 41,83- 45,05 tergolong baik, 2 orang (14,29\%) memilki dayatahan 38,66 - 41,82 tergolong kategori cukup, dan 7 orang (50,00\%) memiliki dayatahan 35,46 - 38,65 tergolong kurang. Sedangkan untuk kategori baik sekali, dan kurang sekali tidak ada (0\%) dimiliki oleh pemain bolavoli putra SMA 2 Pariaman.

\section{PEMBAHASAN}

Berdasarkan analisis dan olahan data mengenai "tinjauan tingkat kondisi fisik pemain bolavoli putra SMA 2 Pariaman, maka pada sub bab ini akan di jawab pertanyaan penelitian sesuai dengan rumusan masalah yang telah diajukan sebelumnya yaitu bagaimana tinjauan tingkat kondisi fisikyang dimiliki pemain bolavoli putra SMA 2 Pariaman yang berkenaan dengan daya ledak otot tungkai, daya ledak otot lengan, dan dayatahan. Untuk lebih jelasnya jawaban dari pertanyaan dapat di uraikan sebagai berikut:

\section{Daya ledak otot tungkai}

Rata-rata tingkat daya ledak otot tungkai yang dimiliki oleh pemain bolavoli putra SMA 2 Pariaman $91,40 \mathrm{~kg} \mathrm{~m} / \mathrm{sec}$ dikategorikan cukup. Artinya daya ledak otot tungkai yang dimiliki pemain bolavoli putra SMA 2 Pariaman di kategorikan belum maksimal. Daya ledak otot tungkai yang baik akan dapat mempengaruhi permainan bola voli seperti saat melakukan lompatan smash. Apabila daya ledak otot tungkai yang dimiliki pemain baik sekali, pemain akan dapat membantu meningkatkan kualitas penampilan permaianan seperti, dengan cepat dan kuat melakukan smash serta memperoleh poin maksimal. Sebaliknya jika daya ledak otot tungkai masih lemah maka akan berpengaruh terhadap penampilan pemain dilapangan khususnya ketika melakuakan penyerangan dan pertahanan.Oleh karena itu,daya ledak otot tungkai terus dilatih dan ditingkatkan melalui program latihan yang disusun berdasarkan program latihan yang sudah terencana dan sistematis. Irawadi (2011) mengatakan bahwa "Program latihan adalah seperangkat rencana kegiatan latihan yang disusun sedemikian rupa sebagai pedoman dalam berlatih untuk jangka waktu tertentu dan tujuan tertentu". Daya ledak otot tungkai mempunyai peranan yang sangat penting untuk menentukan keberhasilan seseorang mencapai prestasi yang maksimal dalam bolavoli. Dengan demikian kemampuan seseorang dalam menggerakkan daya ledak otot tungkai menjadi komponen utama dalam bolavoli, terutama dalam melakukan teknik smash, block, dan servis lompat. Dengan demikian dapat dijelaskan, bahwa program latihan yang direncanakan dan disusun sedemikian rupa berdasarkan ilmu pengetahuan melatih sangat penting dalam membentuk kondisi fisik atlet bolavoli terutama dalam melatih daya ledak otot tungkai.

\section{Daya ledak otot lengan}

Rata-rata tingkat daya ledak otot lengan yang dimiliki oleh pemain bolavoli SMA 2 Pariaman 8,68 meter dikategorikan cukup. Artinya daya ledak otot lengan yang dimiliki pemain bolavoli putra SMA 2 Pariaman di kategorikan belum maksimal. Dalam permainan bolavoli daya ledak otot lengan diperlukan ketika sedang bermain terutama saat melakukan passing dan smash. Apabila tidak memiliki daya ledak otot lengan yang baik, maka ketika melakukan smash tidak akan maksimal. Dengan daya ledak yang maksimal seorang spike akan bisa memukul bola dengan keras dan cepat yang akan menyulitkan lawan untuk bertahan dan mengancang untuk menyerang balasan. Artinya kemampuan otot lengan berkontraksi dengan cepat dan singkat dalm mengeluarkan kekuatan semaksimal mungkin. Khususnya pada permainan bolavoli daya ledak 
otot lengan sangat diperlukan untuk menyerang lawan, karena dengan serangan yang kuat dan cepat bisa memecahkan pertahanan lawan. Oleh karena itu, daya ledak otot lengan terus dilatih dan ditingkatkan minsalnya dengan melakukan smash berturut-turut, melakukan push-up, latihan lempar bola sejauh mungkin dan latihan lain yang menunjang daya ledak otot lengan. Disamping itu sarana dan prasarana sebagai pendukung dalam meningkatkan daya ledak otot lengan. Menurut Syafruddin (2011) bahwa "sarana prasarana merupakan faktor eksternal yang mempengaruhi prestasi kondisi fisik".

\section{Dayatahan}

Rata-rata tingkat dayatahan yang dimiliki pemain bolavoli putra SMA 2 Pariaman adalah 40,26 dikategorikan cukup Artinya daya ledak otot lengan yang dimiliki pemain bolavoli putra SMA 2 Pariaman di kategorikan belum maksimal. Permainan bolavoli dalam suatu pertandingan menggunakan waktu relative lama, bisa berjam-jam lamanya, bahkan bisa terjadi babak tambahan. Hal ini menuntut kemampuan pemain bolavoli untuk melakukan kerja fisik dalam waktu relative lama. Sesuai dengan pendapat Syafruddin (2011) "dayatahan diartikan sebagai kemmpuan organisme tubuh terutama jantung, paru dan sistem peredaran darah untuk mengatasi kelelahan yang disebabkan oleh pembebanan latihan yang berlangsung relatif lama”.

Dayatahan sering juga disebut dengan kardiorespiratori atau dayatahan kardiovaskuler, sehingga kapasitas sistem sirkulasi (jantung, pembuluh darah dan darah), dan sistem respirasi (paru) untuk menyampaikan oksigen ke otot yang sedang bekerja dan mengangkut limbah dari otot-otot berfungsi dengan baik. Dayatahan ini dibutuhkan atlet bolavoli ketika mengatasi kelelahan yang disebabkan pembebanan latihan dalam bermain relative lama.

Agar dayatahan tetap maksimal, maka dayatahan terus dilatih dan ditingkatkan melalui program latihan yang disusun berdasarkan program latihan yang sudah terencana dan sistematis. Selain itu diduga kurangnya motivasi atlet dalam latihan. "Motivasi menunjukkan kadar keinginan seseorang untuk memenuhi kebutuhannya. Artinya makin tinggi motivasi, maka makin tinggi pula kebutuhannya akan sesuatu. Semakin penting kebutuhan tersebut untuk dipenuhi, maka makin besar pulalah usaha yang dilakukannya" (Irawadi 2014). Dengan demikian dalam latihan kondisi fisik diperlukan motivasi yang tinggi, karena untuk membentuk kondisi fisik dibutuhkan keseriusan dan ke disiplinan seorang atlet dalam mengikuti latihan kondisi fisik.

Dengan meningkatnya aktivitas fisik dalam berlatih seperti yang telah dikemukakan di atas, semakin banyak pula oksigen yang dialirkan ke otot yang aktif. Oleh sebab itu faktor utama yang membatasi sebagian besar bentuk latihan yang bersifat aerobik adalah kapasitas jantung, paru dan sirkulasi untuk menyampaikan oksigen ke otot yang sedang bekerja (aktif). Karena faktor yang menentukan dayatahan waktu adalah kapasitas aerobik seseorang, yaitu besarnya penerimaan oksigen $\left(\mathrm{O}_{2}\right)$ dalam satuan waktu. Kemampuan penerimaan oksigen maksimal (kosumsi oksigen maksimal) tergantung dari besarnya volume jantung permenit yang ditentukan oleh frekuensi dan volume denyut jantung.Sehingga kemampuan tubuh dalam mengatasi kelelahan akibat pembebanan relative lama membuat dayatahan pemain menjadi meningkat.

\section{KESIMPULAN}

Berdasarkan hasil penelitian yang telah diuraikan pada bab terdahulu dapat dikemukakan kesimpulan yaitu : Kemampuan daya ledak otot tungkai yang dimiliki pemain bolavoli putra SMA 2 Pariaman dikategorikan cukup, kemampuan daya ledak otot lengan yang dimiliki pemain bolavoli putra SMA 2 Pariaman dikategorikan cukup, kemampuan dayatahan yang dimilik pemain bolavoli putra SMA 2 Pariaman dikategorikan cukup.Olehkarenaitu untuk meningkatkan prestasi pemain bolavoli putra SMA 2 Pariaman disarankan kepada pemain agar serius melakukan latihan kondisi fisik untuk tidak mengabaikan kondisi fisik, karena kondisi fisik merupakan dasar semua cabang olahraga khususnya bolavoli dengan cara latihan terstruktur dan terprogram. Dan untuk pemain hendaknya agar lebih giat lagi dalam latihan baik itu sedang mengikuti latihan dan di luar jam latihan.

\section{DAFTARPUSTAKA}


Arikunto, Suharsimi.2010. Prosedur penelitian.Yogyakarta: RinekaCipta

Aziz, Ishak. 2016. Dasar-dasar Penelitian Olahraga. Jakarta. Kencana.

Bacthiar. 1999. Pengetahuan Dasar Permainan Bolavoli. Padang: FIK UNP.

Firdaus, Efendy. 2017. Pembentukan Kondisi Fisik. Padang: FIK.UNP

Erianti. 2004. Buku Ajar Bolavoli. Padang: FIK UNP 2004. Buku Ajar Bolavoli. Padang: Sukabina Press

Irawadi, Hendri. 2011. Kondisi Fisik dan Pengukurannya. Padang : UNP Press. 2018. Kondisi Fisik dan Pengukurannya. Padang: FIK UNP.

Kemempora, 2005. Undang-Undang RI No. 3 Tahun 2005. Tentang Sistem Keolahrgaan Nasional

Setiawan, Y., Amra, F., \& Lesmana, H. S. (2018). Analisis Tentang Cedera Dalam Olahraga Beladiri TaekwondoDi Dojang UNP. JURNAL STAMINA, 1(1), 401-414.

Saputra, H., Ramadi, R., \& Wijayanti, N. P. N. Hubungan Power Otot Tungkai dan Power Otot Lengan dan Bahu dengan Hasil Smash Bola Voli Tim Ekstrakurikuler Putra SMA Negeri 3 Tualang (Doctoral dissertation, Riau University).

Syafruddin, 2011.IImu Kepelatihan Olahraga. Padang : FIK UNP. 